\title{
Analisis Sentimen Masyarakat Dengan Metode Nä̈ve Bayes dan Particle Swarm Optimization
}

Public Sentiment Analysis using Nä̈ve Bayes Method and Particle Swarm Optimization

\author{
Septiawan Dwi Pramukti ${ }^{1}$, Agung Nugroho ${ }^{2}$, Aswan Supriyadi Sunge ${ }^{3}$ \\ ${ }_{1,2,3}$ Teknik Informatika, Universitas Pelita Bangsa \\ E-mail: 'septiawandpramukti@gmail.com, ${ }^{2}$ agung@pelitabangsa.ac.id, \\ ${ }^{3}$ aswan.sunge@pelitabangsa.ac.id
}

\begin{abstract}
Abstrak
Pemberlakuan Pembatasan Kegiatan Masyarakat (PPKM) merupakan kebijakan yang di terapkan pada 15 Kota diluar pulau Jawa dan pulau Bali yang memiliki status zona merah atau daerah yang memiliki risiko tinggi terhadap paparan kasus COVID-19. Pada tanggal 3 Agustus 2021 kebijakan PPKM darurat di beberapa daearah di kepulauan Jawa dan kepulauan Bali di perpanjang sampai 9 Agustus 2021, perpanjangan kebijakan PPKM darurat menuai banyak komentar dari masyarakat sehingga menimbulkan pro dan kontra pada social media twitter. Penelitian ini bertujuan untuk mengetahui hasil klasifikasi sentimen masyarakat mengenai perpanjangan kebijakan PPKM darurat pada social media twitter dan untuk mengetahui hasil accuracy, precision, recall yang dihasilkan dari metode yang digunakan. Penelitian ini menggunakan metode Nä̈ve Bayes dan Particle Swarm Optimization sebagai feature selection, selain itu terdapat tahap preprocessing yang didalamnya meliputi cleansing, remove duplicate, seleksi data, normalisasi, case folding, tokenizing, filtering, stopwords, stemming, dan labeling. Hasil klasifikasi yang didapat 53,31\% pengguna twitter setuju dan $46,69 \%$ pengguna twitter tidak setuju dengan perpanjangan kebijakan PPKM darurat. Nilai accuracy yang didapatkan meningkat sebanyak 15,21\% dari $77,16 \%$ menjadi $92,37 \%$, nilai precision yang didapatkan meningkat sebanyak 3,07\% dari $87,33 \%$ menjadi $90,40 \%$, dan nilai recall yang didapatkan meningkat sebanyak $30,96 \%$ dari $64,42 \%$ menjadi $95,38 \%$.
\end{abstract}

Kata kunci: Naïve Bayes, Particle Swarm Optimization, Analisis Sentimen, PPKM Darurat

\begin{abstract}
The implementation of Community Activity Restrictions (PPKM) is a policy that is applied to 15 cities outside Java and Bali that have red zone status or areas that have a high risk of exposure to COVID-19 cases. On August 3, 2021, the emergency PPKM policy in several areas in the Java and Bali islands was extended until August 9, 2021, the extension of the emergency PPKM policy drew many comments from the public, causing pros and cons on Twitter social media. This study aims to determine the results of the classification of public sentiment regarding the extension of the emergency PPKM policy on Twitter social media and to find out the results of accuracy, precision, recall resulting from the method used. This study uses the Nä̈ve Bayes method and Particle Swarm Optimization as feature selection, besides that there is a preprocessing stage which includes cleansing, remove duplicates, data selection, normalization, case folding, tokenizing, filtering, stopwords, stemming, and labeling. The classification results obtained are $53.31 \%$ of twitter users agree and 46.69\% of twitter users do not agree with the extension of the emergency PPKM policy. The accuracy value obtained increased by $15.21 \%$ from $77.16 \%$ to $92.37 \%$, the precision value obtained increased by $3.07 \%$ from $87.33 \%$ to $90.40 \%$, and the recall value obtained increased by $30,96 \%$ from $64.42 \%$ to $95.38 \%$.
\end{abstract}

Keywords: Naïve Bayes, Particle Swarm Optimization, Sentiment Analysis, Emergency PPKM 


\section{PENDAHULUAN}

Covid-19 merupakan penyakit yang mucul pertama kali di daerah Wuhan, Tiongkok yang disebabkan oleh coronavirus jenis baru dengan tingkat penularan yang tinggi, pada bulan Desember 2019 World Health Organization (WHO) meberikan nama untuk coronavirus jenis baru dengan sebutan Severe Acute Respiratory Syndrome Coronavirus 2 (Sars-Cov2), Sars-Cov2 ini lah yang menjadi awal mula penyebab Covid-19 [1]. Covid-19 merupakan virus yang sampai saat ini masih menjadi trending topic diseluruh negara, termasuk negara Indonesia. Mulai dari awal kasus Covid-19 sampai saat ini, pasien terkonfirmasi positif Covid-19 di Indonesia setiap hari terus-menerus bertambah. Hal ini lah yang menjadi faktor penyebab pemerintah melakukan berbagai upaya untuk dapat menangani dan mencegah pertumbuhan kasus Covid-19 yang baru, dengan mengeluarkan berbagai kebijakan seperti lockdown, PSBB, dan Pemberlakuan Pembatasan Kegiatan Masyarakat (PPKM). Kebijakan PPKM di terapkan di beberapa daerah di kepulauan Jawa dan kepulauan Bali, yang memiliki status zona merah atau daerah yang memiliki risiko tinggi terhadap paparan kasus Covid-19. Pada 25 Juli 2021 pemerintah Indonesia kembali menerapkan kebijakan pelaksanaan PPKM darurat di beberapa daerah di kepulauan Jawa dan kepulauan Bali, yang berlaku sampai 2 Agustus 2021. Pada tanggal 3 Agustus 2021 kebijakan PPKM darurat di beberapa daearah di kepulauan Jawa dan kepulauan Bali di perpanjang sampai 9 Agustus 2021, perpanjangan kebijakan PPKM darurat menuai banyak respon berupa tweets dari berbagai kalangan masyarakat, sehingga mehasilkan banyak jejak tweets yang di dalamnya berisikan opini masyarakat mengenai perpanjangan kebijakan PPKM darurat pada media sosial twitter. Tweets adalah sebuah kalimat yang berisikan pesan atau status yang dibuat oleh pengguna akun twitter yang di dalamnya mengandung sebuah opini, opini didalam tweets dapat mengekspresikan sebuah perasaaan atau keadaan dari pengguna akun twitter tersebut, tweets juga dapat digunakan sebagai penilaian bagi perusahaan atau instansi [2]. Banyaknya respon masyarakat Indonesia dalam menilai kebijakan pemerintah menjadi acuan bagi peneliti untuk melakukan analisis sentimen masyarakat mengenai kebijakan perpanjangan PPKM darurat pada social media twitter.

Pemberlakuan Pembatasan Kegiatan Masyarakat (PPKM) merupakan kebijakan yang di terapkan pada 15 Kota diluar pulau Jawa dan pulau Bali yang memiliki status zona merah atau daerah yang memiliki risiko tinggi terhadap paparan kasus COVID-19 [3]. Proses pengambilan data yang berisikan informasi penting yang didapatkan dari suatu media penyimpanan (database) merupakan definisi data mining [4]. Digunakan teknik matematika, statistika, kecerdasan buatan, dan machine pada data mining [5]. Tujuan data mining untuk klasifikasi, klasterisasi, mendapatkan pola asosiasi sampai melakukan sebuah peramalan (predicting) [6]. Association rule mining, clustering, dan klasifikasi merupakan 3 teknik yang sangat popular [7]. Text mining biasanya digunakan dalam mengklasifikasi sebuah dokumen yang berisikan teks [8]. Tahapan pada text mining terdiri dari teks, pengolahan teks (tokenisasi), perubahan teks (stemming), pemilihan teks (filtering), data mining (pattern discovery), dan evaluasi [9]. Preprocessing adalah tahap penghapusan teks yang tidak dibutuhkan dan tidak digunakan pada saat proses klasifikasi teks [10]. Preprocessing dilakukan bertujuan untuk memperbaiki data yang sebelumnya tidak tersetruktur menjadi data yang terstruktur, tujuannya untuk dapat mempermudah dan mempercepat pemrosesan data [11]. Terdapat beberapa tahap pada preprocessing contohnya seperti tokenize, transform cases, filter tokens, filter stopword, dan stemming [8]. Natural Language Processing (NLP) merupakan bidang penelitian baru dalam analisis sentimen [11]. Opinion Mining adalah bidang studi yang dipakai untuk menganalisis suatu pendapat atau pandangan, penilaian atau evaluasi, sikap, dan luapan perasaan terhadap entitas dan aspek-aspek lainnya yang diungkapkan dengan sebuah teks [12]. Tujuan dari analisis sentimen yaitu untuk menentukan polaritas dari suatu teks [13]. Untuk melakukan analisis sentimen terdapat beberapa tahap yang harus di lakukan antara lain menentukan sebuah dataset, preprocessing, pemilihan feature selection, pemberian label sentimen, klasifikasi dan evaluasi [14].

Penelitian yang dilakukan oleh Renaldy Permana Sidiq, Budi Arif Dermawan, \& Yunun Umaidah [10] yang berjudul "Sentimen Analisis Komentar Toxic pada Grup Facebook Game 
Online Menggunakan Klasifikasi Nä̈ve Bayes", penelitian ini membahas tentang analisis komentar toxic pada grup facebook game online arena of valor. Tujuan dari penelitian ini untuk melakukan klasifikasi sentiment toxic, dan non-toxic terhadap data uji, dan juga membandingkan akurasi klasifikasi menggunakan metode Nä̈ve Bayes dengan transformasi TF-IDF, tanpa TFIDF dan seleksi fitur Information Gain serta menggunakan rasio pembagian data 80:20. Dataset yang digunakan berjumlah 1.500 yang di ambil dari media social facebook. Dikarenakan jumlah kata non-toxic cenderung lebih sering muncul pada wordcloud hasil klasifikasi sentimen cenderung non-toxic dengan jumlah 1.237 komentar dan toxic dengan jumlah 263 komentar. Hasilnya klasifikasi Nä̈ve Bayes yang menggunakan transformasi TF-IDF menghasilkan nilai akurasi tertinggi dengan akurasi sebesar 75\%, precision sebesar 63\%, recall sebesar 67\%, dan Fmeasure sebesar $64 \%$. Selanjutnya penelitian yang dilakukan oleh Hennie Tuhuteru, \& Ade Iriani [11] yang berjudul "Analisis Sentimen Perusahaan Listrik Negara Cabang Ambon Menggunakan Metode Suport Vector Machine dan Naïve Bayes Classifier", dataset yang digunakan berjumlah 1492 tweet berasal dari tweet yang di mention ke akun @ambonlima dan keyword "PLN Ambon" data diambil menggunakan metode snipping. Tujuan dari penelitian ini untuk dapat mengetahui sentimen masyarakat terhadap kondisi kelistrikan, khususnya pemadaman listrik yang terjadi di Pulau Ambon. Text pre-processing dilakukan melalui 6 tahapan yaitu cleansing, case folding, tokenizing, normalization, filtering, dan stemming. Pada penelitian ini digunakan 2 metode yaitu Nä̈ve Bayes Classifier dan Suport Vector Machine untuk dibandingkan metode mana yang memberikan hasil terbaik. Hasil dari penelitian menggunakan metode NBC diketahui bahwa sentiment masyarakat cenderung positif dengan nilai akurasi $67.20 \%$, namun hasilnya cenderung negatif jika menggunakan metode SVM dengan tingkat akurasi $81.67 \%$. Jika dibandingkan metode SVM lah yang memiliki nilai akurasi yang lebih baik, namun seiring bertambahnya nilai fold pada proses validasi, metode SVM membutuhkan waktu yang lebih lama dibandingkan metode NBC. Proses pengujian pada K-Fold Cross Validation sangat berpengaruh dalam meningkatkan akurasi metode klasifikasi NBC dan SVM. Hasil analisis sentiment dengan menggunakan metode klasifikasi NBC menghasilkan sentimen positif sebesar $67 \%$, sentimen netral 19\%, dan sentiment negative 14\%. Pada metode klasifikasi SVM menghasilkan sentimen positif sebesar 24\%, sentimen negative 47\%, dan sentimen netral $29 \%$.

Penelitian yang di lakukan oleh Yono Cahyono, dan Saprudin [15] yang berjudul "Analisis Sentiment Tweets Berbahasa Sunda Menggunakan Nä̈ve Bayes Classifier dengan seleksi fitur Chi Squared Statistic", penelitian ini menggunakan metode Nä̈ve Bayes Classifier dan seleksi fitur Chi Squared Statistic. Dataset yang digunakan berjumlah 316 tweets yang di dalamnya berisikan kalimat campuran bahasa Sunda dan bahasa Indonesia, dataset berasal dari twitter yang diambil dengan cara crawl data pada sosial media twitter dengan menggunakan RapidMiner. Tahap pre-processing yang dilakukan pada penelitian ini menggunakan case folding, tokenize, dan stopword removal. Seleksi fitur chi square statistic dilakukan optimize selection dengan menggunakan forward selection, chi square statistic dilakukan untuk memilih kata atau term apa saja yang dapat dijadikan sebagai wakil penting untuk kumpulan dokumen yang akan dianalisis. Menggunakan standar validasi 10-fold validation untuk meningkatkan akurasi klasifikasi. Hasil penelitian ini menunjukan penggunaan seleksi fitur Chi Square Statistic dan algoritma Nä̈ve Bayes Classifier mendapatkan akurasi sebesar 78.48\%. Selanjutnya penelitian yang dilakukan oleh Yono Cahyono [2] dengan judul "Analisis Sentiment Pada Sosial Media Twitter Menggunakan Nä̈ve Bayes Classifier Dengan Feature Selection Particle Swarm Optimization Dan Term Frequency", penelitian ini bertujuan untuk memisahkan sentimen tweets berbahasa Indonesia pada media sosial twitter dan mengetahui hasil dari akurasi yang didapatkan. Penggunaan metode Nä̈ve Bayes Classifier (NBC) dengan feature selection Particle Swarm Optimization (PSO) dan Term Frequency bertujuan untuk mengurangi atribut yang kurang relevan pada saat proses klasifikasi. Tahap text processing yang ada pada penelitian ini antara lain case folding, tokenizing, stopword removal. Untuk mendapatkan hasil validasi yang akurat peneliti menggunakan stratified 10-fold cross-validation. Hasil penelitian penggunaan seleksi fitur PSO menggunakan parameter term frequensi (TF) dengan metode NBC hasil term yang terseleksi sebanyak 776 kata, sedangkan seleksi fitur PSO menggunakan parameter TF-IDF 
dengan metode NBC terms yang didapatkan berjumlah 774. Hasil pengujian seleksi fitur PSO terbukti dapat meningkatkan akurasi algoritma Nä̈ve bayes classifier, hasil akurasi yang di dapat setelah pengujian seleksi fitur PSO menggunakan parameter term frequency (TF) dengan metode Nä̈ve Bayes Classifier sebesar 97,48\%.

Penelitian terdahulu yang dilakukan oleh Karno Juni Prayoga, Agung Nugroho, dan Tri Ngudi Wiyatno [12] yang berjudul "Komparasi Feature Selection Particle Swarm Optimization (PSO) Dengan Genetic Algorithm (GA) Terhadap Algoritma Naïve Bayes pada Analisis Sentiment Twitter". Penelitian ini bertujuan untuk membandingkan feature selection Particle Swarm Optimization dan Genetic Algorithm dalam meningkatkan kinerja akurasi dari algoritma Nä̈ve Bayes. Dataset yang digunakan adalah komentar yang berasal dari akun twitter @ hendralm. Terdapat tahap preprocessing sebagai pemrosesan data awal yang terdiri dari seleksi data, remove duplicate, cleansing, normalisasi kata, dan penentuan kelas attribut. Selain itu terdapat process document yang didalamnya terdiri dari transform case, tokenization, filter tokens (By Length), filter stopwords, stemming, dan $\mathrm{N}$-Gram (bigram). Hasil dari pengujian yang dilakukan terdapat peningkatan akurasi pada algoritma Nä̈ve Bayes dengan feature selection Particle Swarm Optimization dari $67.17 \%$ menjadi $71.84 \%$, dan terdapat peningkatan pula pada akurasi algoritma Naïve Bayes dengan feature selection Genetic Algorithm dari 67.71\% menjadi 68.96\%. Dengan demikian dapat diketahui bahwa Particle Swarm Optimization adalah feature selection terbaik dengan peningkatan akurasi sebesar $4.00 \%$. Oleh karena itu, peneliti tertarik menggunakan metode Naïve Bayes dalam menganalisis sentimen masyarakat pada sosial media twitter, dikarenakan berdasarkan hasil literatur menunjukan bahwa metode Naïve Bayes adalah metode sederhana yang mempunya nilai accuracy dan performasi yang tinggi untuk mengklasifikasi sebuah teks. Untuk mendapatkan hasil akurasi yang lebih baik, ditambahkan Particle Swarm Optimization sebagai feature selection. Penelitian ini dilakukan bertujuan untuk mengetahui hasil klasifikasi sentimen masyarakat mengenai perpanjangan kebijakan PPKM darurat pada social media twitter dan untuk mengetahui perbandingan nilai accuracy, precision, recall yang dihasilkan dari metode yang digunakan yaitu metode Nä̈ve Bayes dan PSO.

\section{METODE PENELITIAN}

\subsection{Pengumpulan Data}

Data set yang digunakan dalam penelitian ini berasal dari social media twitter yang diambil melalui situs https://www.twitter.com, yang dilakukan dengan cara crawling data. Pengumpulan data twitter diambil melalui operator search twitter yang ada pada software RapidMiner Studio. Data tweet yang diambil berisikan pendapat masyarakat mengenai perpanjangan kebijakan PPKM darurat di Indonesia yang diambil pada tanggal 2 Agustus 2021, pada jam 18:40 wib sampai 21:11 wib malam dengan query "PPKM Diperpanjang", result type "recent or popular", limit "3000", dan language "id".

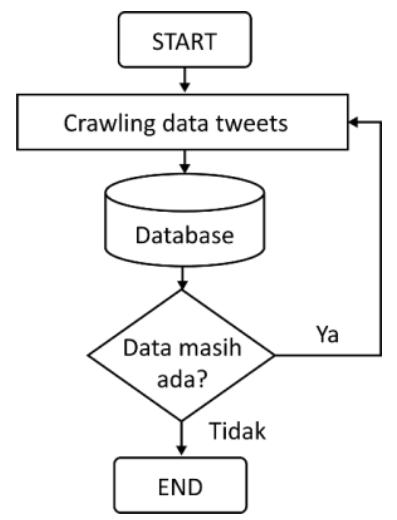

Gambar 1 Alur proses crawling data 


\subsection{Preprocessing}

Tahap preprocessing adalah tahap yang dipakai untuk mengahapus kata atau teks yang tidak dibutuhkan dalam proses klasifikasi. Terdapat beberapa proses yang terdapat pada tahap preprocessing yang terdiri dari cleansing, remove duplicate, sleksi data, normalisasi, transform case, tokenizing, filtering, stopword, stemming, dan pemberian label (labeling). Dibawah ini merupakan penjelasan mengenai proses-proses yang ada pada tahap preprocessing.

\section{Cleansing}

Tahap cleansing atau tahap pembersihan data bertujuan untuk menghapus special karakter (simbol), nama username, retweet (RT), dan link yang terdapat didalam dataset.

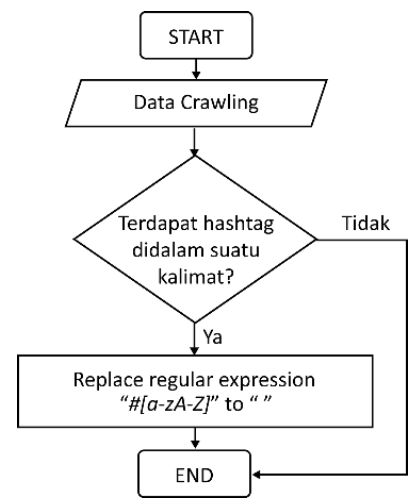

Gambar 2 Alur dari proses cleansing

\section{Remove duplicate}

Tahap yang berfungsi untuk menghapus atribut yang bernilai sama (duplicate) didalam data yang di crawling.

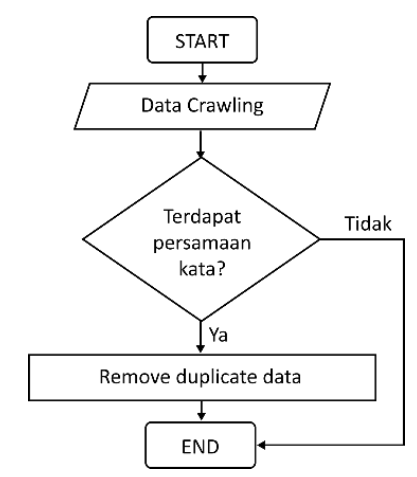

Gambar 3 Alur remove duplicate

\section{Seleksi data}

Tahap seleksi data adalah tahap penghapusan beberapa data tweet yang tidak berhubungan dengan perpanjangan PPKM darurat, contohnya seperti tweet promosi penjualan suatu produk dan tweet informasi berita dari berbagai situs yang di share kedalam twitter. Setelah dilakukan proses seleksi data dari 3000 dataset didapatkan total 302 dataset yang berhubungan dengan perpanjangan PPKM darurat.

\section{Normalisasi}

Normalisasi merupakan tahap untuk mengubah kata-kata yang terdapat pada dataset twitter yang sebelumnya kata tersebut tidak baku menjadi kata dasar yang baku atau sesuai ejaan kata yang benar. Normalisasi dilakukan dikarenakan kebiasaan pengguna twitter yang menggunakan kata singkatan ataupun kata gaul dalam menulis sebuah tweet. 


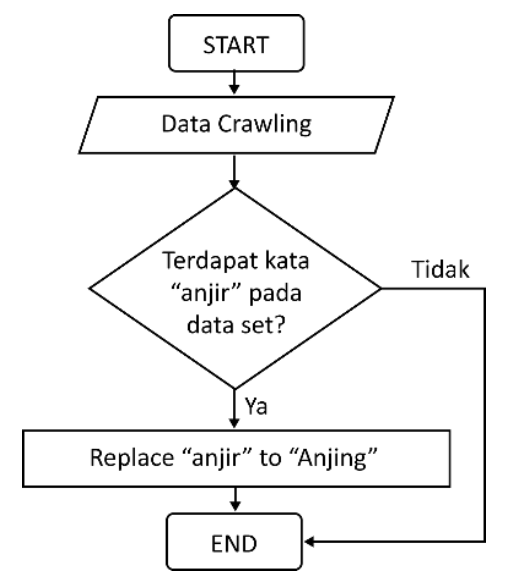

Gambar 4 Alur proses normalisasi teks

\section{Transform case}

Transform case merupakan proses untuk mengubah semua huruf besar atau uppercase yang terdapat didalam dataset menjadi huruf kecil atau lowercase.

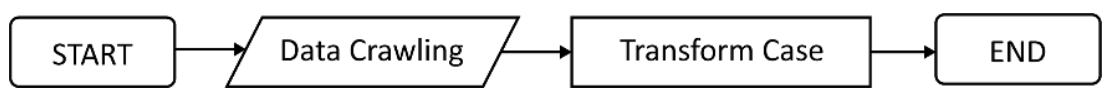

Gambar 5 Alur proses transform case

\section{Tokenize}

Tokenize merupakan tahap untuk memecah kalimat yang ada didalam data tweet (dataset), data yang asalnya berbentuk sebuah kalimat akan di ubah ke bentuk kata perkata.

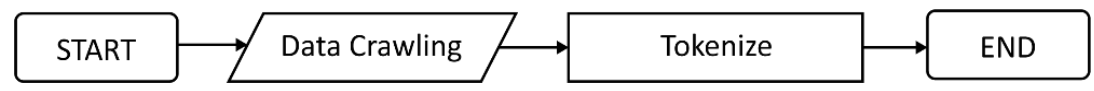

Gambar 6 Alur proses tokenize

\section{Filtering}

Filtering merupakan tahap menghilangkan kata-kata (setelah proses tokenize) yang tidak memiliki nilai dalam proses klasifikasi teks. Pada penelitian yang dilakukan, kata yang didalam dataset memiliki nilai kurang dari 4 karakter dan panjang melebihi 25 karakter akan hapus atau dihilangkan.

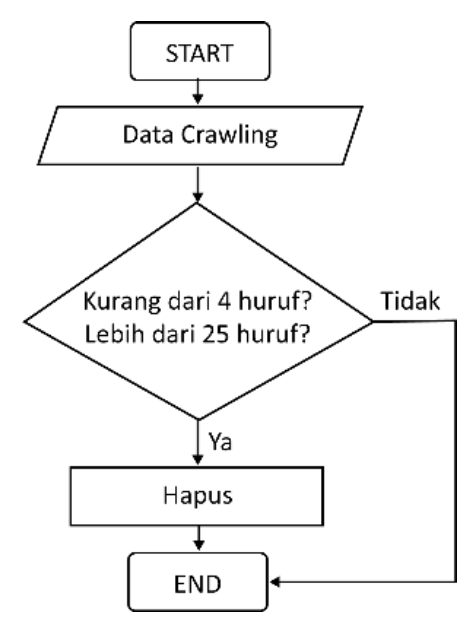

Gambar 7 Alur dari proses filtering 


\section{Stopwords}

Stopwords Stopwords merupakan proses menghilangkan kata sambung yang ada didalam dataset. Data stopwords yang didapatkan bersumber dari website https://github.com/masdevid/ID-Stopwords dengan total berjumlah 758 kata.

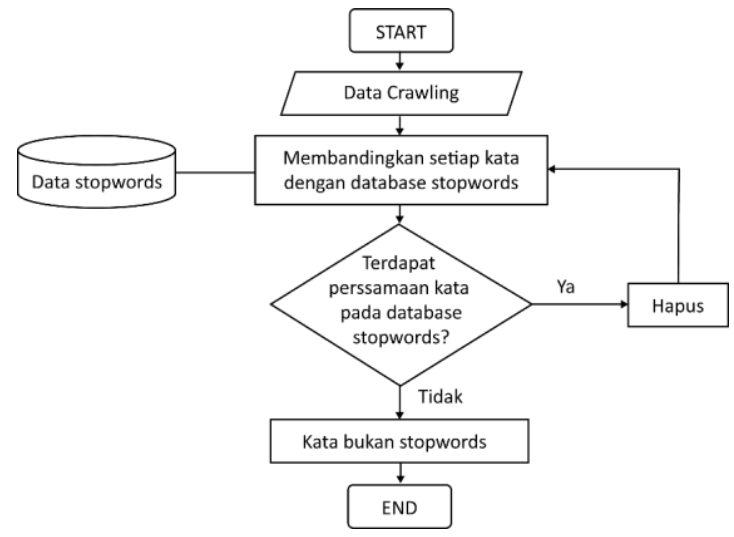

Gambar 8 Alur dari proses stopwords

\section{Stemming}

Stemming merupakan tahap akhir dalam tahap preprocessing, stemming adalah proses menghilangkan semua imbuhan (prefix dan sufixs) yang ada pada awal dan akhir kata. Kata dasar atau data stem didapatkan dari website https://github.com/sastrawi/sastrawi/tree/master/data dengan total berjumlah 30342 kata dasar.

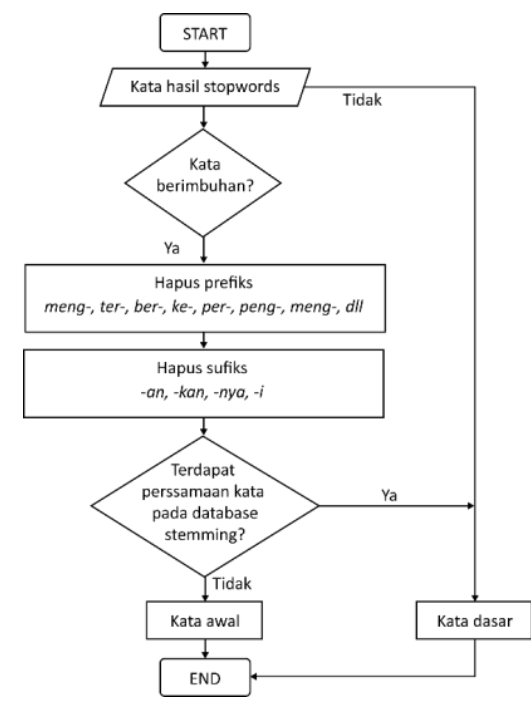

Gambar 9 Alur dari proses stemming

\section{Labeling}

Labeling atau pemberian label merupakan tahap untuk menentukan respon tweet yang ada didalam dataset yang dilakukan secara manual, pendapat yang ada pada dataset akan dibagi dua menjadi pendapat positif dan negatif. Pendapat yang berisikan kalimat pujian atau dukungan terhadap perpanjangan kebijakan PPKM akan dikelompokan ke dalam sentimen positif. Pendapat yang berisikan kata-kata atau kalimat ketidak setujuan, ataupun kata-kata kasar berdasarkan kamus bad words pada website https://github.com/masdevid/ID-OpinionWords akan di masukan kedalam sentimen negatif. Didapatkan 302 tweets mengandung sentimen yang terdiri dari 152 tweets bersentimen positif dan 150 tweets bersentimen negatif. 
Table 1 Contoh sentimen positif dan negatif

\begin{tabular}{|c|c|}
\hline Tweets & Label \\
\hline selamat atlet berjuang semangat rakyat berjuang pemberlakuan pembatasan kegiatan masyarakat \\
diperpanjang agustus & Positif \\
\hline anjing pemberlakuan pembatasan kegiatan masyarakat diperpanjang & Negatif \\
\hline pemberlakuan pembatasan kegiatan masyarakat diperpanjang tolong siaran badminton perbanyak & Positif \\
\hline bangsat pemberlakuan pembatasan kegiatan masyarakat diperpanjang & Negatif \\
\hline
\end{tabular}

\subsection{Metode yang digunakan}

Penelitian ini menggunakan metode Naïve Bayes dan menambahkan Particle Swarm Optimization sebagai feature selection. Untuk mengetahui hasil evaluasi accuracy, precision, recall dari penggunaan metode Nä̈ve Bayes dan Particle Swarm Optimization akan digunakan teknik Cross Validation dengan nilai $K=10$.

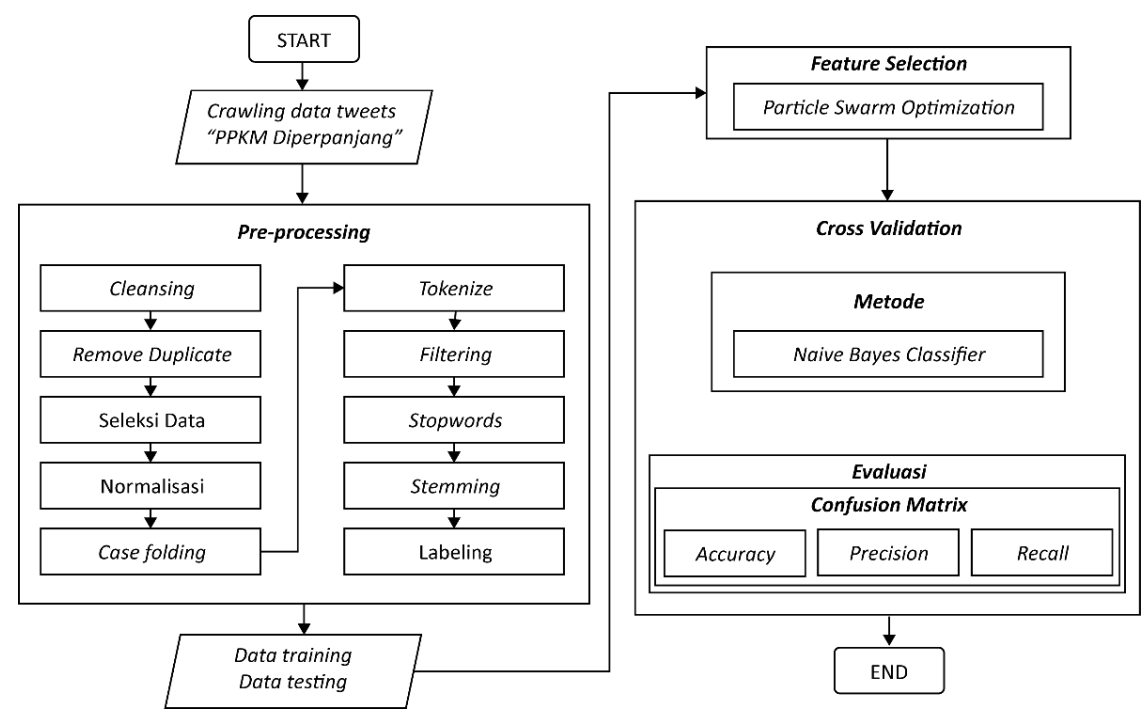

Gambar 10 Metode yang digunakan

\section{HASIL DAN PEMBAHASAN}

Pada tahap proses pengujian, dalam penelitian ini digunakan metode Nä̈ve Bayes dan Particle Swarm Optimization sebagai feature selection. Proses pengujian metode dilakukan sebanyak 2 kali, untuk mengetahui hasil perbandingan accuracy, precision, recall dari penggabungan ke dua metode. Pada proses pengujian pertama dilakukan hanya dengan menggunakan metode Nä̈ve Bayes dan pada proses pengujian kedua dilakukan menggunakan metode Nä̈ve Bayes dengan Particle Swarm Optimzation.

\subsection{Proses pengujian pertama}

Pengujian pertama dilakukan dengan metode Nä̈ve Bayes tanpa Particle Swarm Optimization. Data yang digunakan berjumlah 302 data tweets, terdiri dari 152 tweets positif, dan 150 tweets negatif.

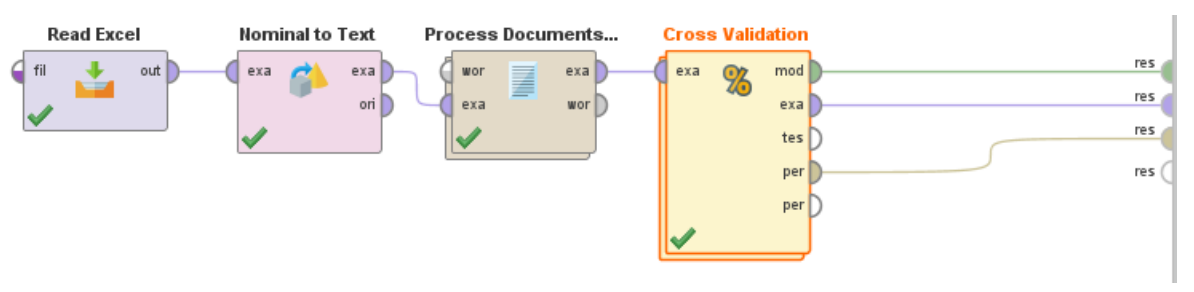

Gambar 11 Model pengujian pertama hanya menggunakan metode Naive Bayes 
Untuk mengetahui hasil evaluasi dari accuracy, precision, recall yang dihasilkan, pada pengujian pertama ini digunakan teknik Cross Validation menggunakan nilai K=10. Dibawah ini merupakan hasil Confusion Matrix pengujian metode Nä̈ve Bayes tanpa Particle Swarm Optimization.

1. Accuracy

Hasil accuracy dari penggunaan algorima Nä̈ve Bayes tanpa Particle Swarm Optimization sebesar 77,16\%, yang bisa dilihat pada gambar 12 .

\begin{tabular}{|c|c|c|c|}
\hline & true Negatif & true Positif & class precision \\
\hline pred. Negatif & 135 & 54 & $71.43 \%$ \\
\hline pred. Positif & 15 & 98 & $86.73 \%$ \\
\hline class recall & $90.00 \%$ & $64.47 \%$ & \\
\hline
\end{tabular}

Gambar 12 Hasil accuracy dari algoritma Naive Bayes tanpa PSO

\section{Precision}

Hasil precision dari penggunaan algorima Nä̈ve Bayes tanpa Particle Swarm Optimization sebesar 87,33\%, yang bisa dilihat pada gambar 13 .

\begin{tabular}{|l|l|l|l|}
\hline \multicolumn{5}{|l}{ precision: $\mathbf{8 7 . 3 3 \% + l - 6 . 6 3 \%}$ (micro average: $\mathbf{8 6 . 7 3 \% )}$ (positive class: Positif) } & class precision \\
\hline & true Negatif & true Positif & $71.43 \%$ \\
\hline pred. Negatif & 135 & 54 & $86.73 \%$ \\
\hline pred. Positif & 15 & 98 & \\
\hline class recall & $90.00 \%$ & $64.47 \%$ &
\end{tabular}

Gambar 13 Hasil precision dari algoritma Naive Bayes tanpa PSO

\section{Recall}

Hasil recall dari penggunaan algorima Nä̈ve Bayes tanpa Particle Swarm Optimization sebesar 64,42\%, yang bisa dilihat pada gambar 14 .

\begin{tabular}{|c|c|c|c|}
\hline & true Negatif & true Positif & class precision \\
\hline pred. Negatif & 135 & 54 & $71.43 \%$ \\
\hline pred. Positif & 15 & 98 & $86.73 \%$ \\
\hline class recall & $90.00 \%$ & $64.47 \%$ & \\
\hline
\end{tabular}

Gambar 14 Hasil recall dari algoritma Naive Bayes tanpa PSO

\subsection{Proses pengujian kedua}

Pengujian kedua dilakukan dengan metode Nä̈ve Bayes dan Particle Swarm Optimization sebagai feature selection. Data yang digunakan sama seperti pengujian pertama yaitu berjumlah 302 data tweets, terdiri dari 152 tweets positif, dan 150 tweet negatif.

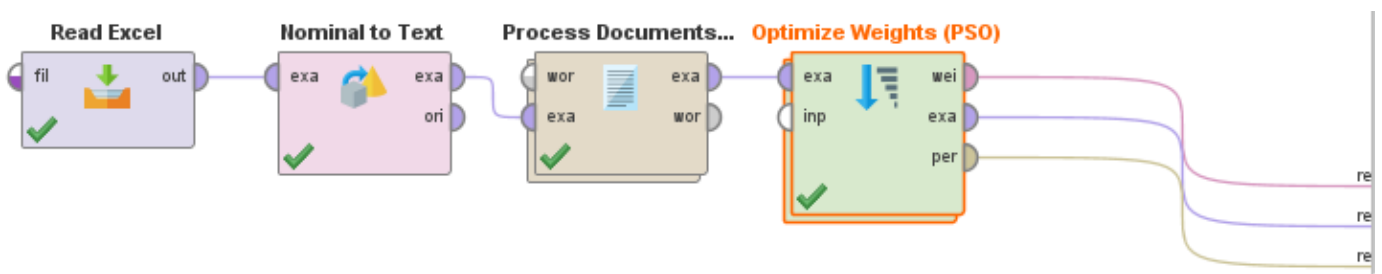

Gambar 15 Pengujian kedua dengan metode Naive Bayes dan feature selection PSO 


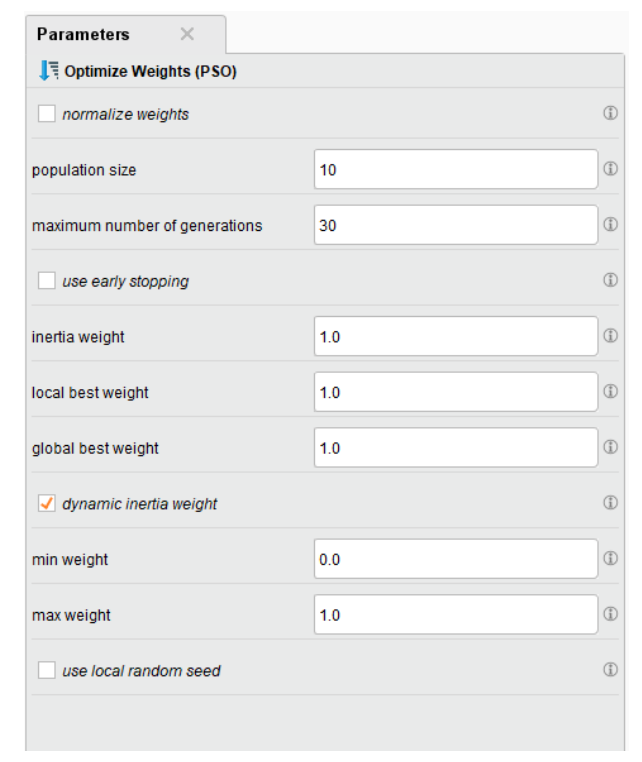

Gambar 16 Parameters PSO

Untuk mengetahui hasil evaluasi dari accuracy, precision, recall yang dihasilkan, pada pengujian kedua ini digunakan teknik Cross Validation menggunakan nilai $K=10$. Untuk pengujian ke dua pada parameter Optimize Weight (PSO) dilakukan perubahan nilai population size menjadi "10" dan nilai inertia weight menjadi "1.0" atau dapat dilihat pada gambar 16. Dibawah ini merupakan hasil Confusion Matrix pengujian metode Naïve Bayes dengan Particle Swarm Optimization.

\section{Accuracy}

Hasil accuracy dari pengujian algorima Naïve Bayes dengan Particle Swarm Optimization sebesar 92,37\%, yang bisa dilihat pada gambar 17 .

\begin{tabular}{|c|c|c|c|}
\hline & true Negatif & true Positif & class precision \\
\hline pred. Negatif & 134 & 7 & $95.04 \%$ \\
\hline pred. Positif & 16 & 145 & $90.06 \%$ \\
\hline class recall & $89.33 \%$ & $95.39 \%$ & \\
\hline
\end{tabular}

Gambar 17 Hasil accuracy dari algoritma Naive Bayes dengan PSO

\section{Precision}

Hasil precision dari pengujian algorima Nä̈ve Bayes dengan Particle Swarm Optimization sebesar 90,40\%, yang bisa dilihat pada gambar 18 .

\begin{tabular}{|l|l|l|l|}
\hline \multicolumn{2}{|c|}{ precision: $\mathbf{9 0 . 4 0 \% + / - 6 . 8 7 \%}$ (micro average: $\mathbf{9 0 . 0 6 \% )}$ (positive class: Positif) } & class precision \\
\hline & true Negatif & true Positif & $95.04 \%$ \\
\hline pred. Negatif & 134 & 7 & $90.06 \%$ \\
\hline pred. Positif & 16 & 145 & \\
\hline class recall & $89.33 \%$ & $95.39 \%$ & \\
\hline
\end{tabular}

Gambar 18 Hasil precision dari algoritma Naive Bayes dengan PSO

\section{Recall}

Hasil recall dari pengujian algorima Nä̈ve Bayes dengan Particle Swarm Optimization sebesar 95,38\%, yang bisa dilihat pada gambar 19 . 


\begin{tabular}{|l|l|l|l|}
\hline \multicolumn{2}{|l}{ recall: $\mathbf{9 5 . 3 8 \% + l - 3 . 1 9 \%}$ (micro average: $95.39 \%)$ (positive class: Positif) } & \\
\hline & true Negatif & true Positif & class precision \\
\hline pred. Negatif & 134 & 7 & $95.04 \%$ \\
\hline pred. Positif & 16 & 145 & $90.06 \%$ \\
\hline class recall & $89.33 \%$ & $95.39 \%$ & \\
\hline
\end{tabular}

Gambar 19 Hasil recall dari algoritma Naive Bayes dengan PSO

\subsection{Hasil klasifikasi sentimen masyarakat}

Hasil klasifikasi setimen masyarakat terhadap perpanjangan kebijakan PPKM darurat yang dihasilkan berasal dari data training yang sebelumnya sudah dilakukan pengujian dengan 2 metode yang berbeda. Dibawah ini merupakan gambar grafik perbandingan hasil klasifikasi sentimen masyarakat terhadap perpanjangan kebijakan PPKM darurat.

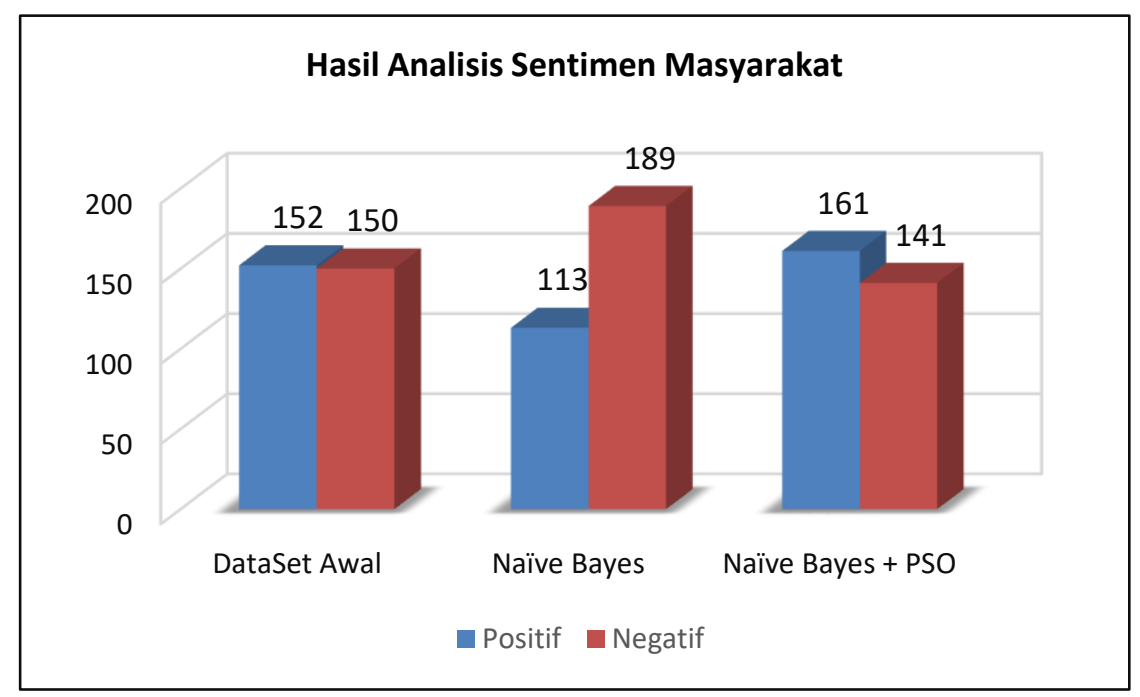

Gambar 20 Grafik perbandingan hasil analisis sentimen masyarakat

Dapat dilihat pada gambar grafik diatas bahwa dari total 302 data tweets yang di uji pada proses pengujian pertama hasilnya 113 data tweets mengandung sentimen positif dan 189 data tweets mengandung sentimen negatif. Pada proses pengujian kedua hasilnya terdapat 161 data tweets mengandung sentimen positif dan 141 data tweets mengandung sentimen negatif.

Dari gambar grafik diatas dapat diketahui bahwa hasil klasifikasi sentimen masyarakat dari pengujian pertama hasilnya lebih unggul tweets negatif dengan persentase $37,42 \%$ tweets mengandung sentimen positif dan 62,58\% tweets mengandung sentimen negatif. Dari pengujian kedua hasilnya lebih unggul tweets positif dengan presentase $53,31 \%$ tweets mengandung sentimen positif dan $46,69 \%$ tweets mengandung sentimen negatif.

Table 2 Hasil analisis sentimen

\begin{tabular}{|c|c|c|c|c|c|c|c|}
\hline \multirow{2}{*}{ Pengujian } & \multirow{2}{*}{ Accuracy } & \multirow{2}{*}{ Precision } & \multirow{2}{*}{ Recall } & \multicolumn{2}{|c|}{$\begin{array}{c}\text { Hasil Klasifikasi } \\
\text { Sentimen }\end{array}$} & \multicolumn{2}{|c|}{ Keterangan } \\
\cline { 5 - 8 } & & & & Positif & Negatif & Positif & Negatif \\
\hline Dataset & - & - & - & 152 & 150 & $50,33 \%$ & $49,67 \%$ \\
\hline $\boldsymbol{N B}$ & $77,16 \%$ & $87,33 \%$ & $64,42 \%$ & 113 & 189 & $37,42 \%$ & $62,58 \%$ \\
\hline $\boldsymbol{N B}+\boldsymbol{P S O}$ & $92,37 \%$ & $90,40 \%$ & $95,38 \%$ & 161 & 141 & $53,31 \%$ & $46,69 \%$ \\
\hline
\end{tabular}

\subsection{Pembahasan}

Dibawah ini merupakan gambar grafik perbandingan hasil accuracy, precision, recall dari metode Nä̈ve Bayes tanpa feature selection PSO dan metode Nä̈ve Bayes dengan feature selection PSO. 


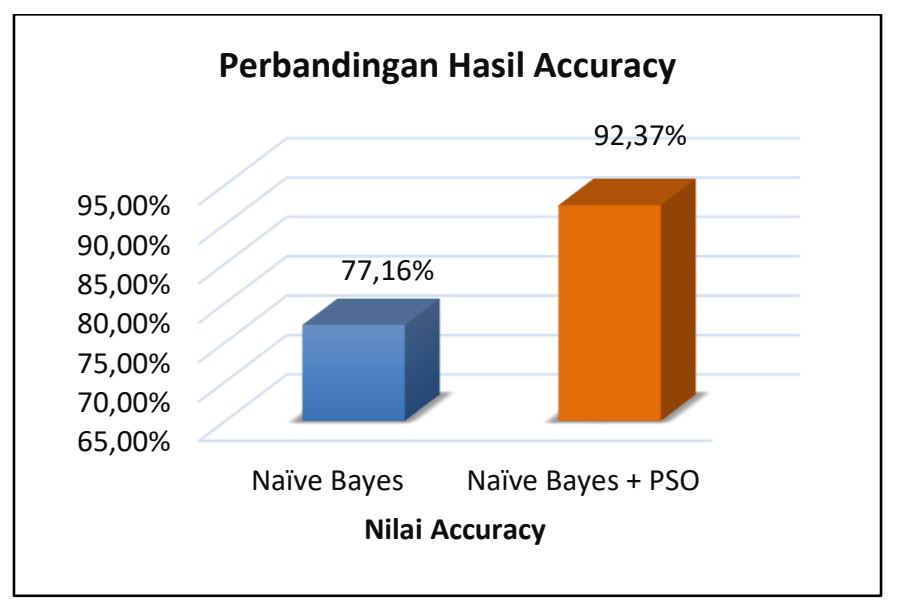

Gambar 21 Grafik perbandingan hasil accuracy

Dari hasil pengujian yang telah dilakukan antara pengujian pertama dan kedua, pada gambar 21 bahwa nilai accuracy yang didapatkan meningkat sebanyak 15,21\% dari 77,16\% menjadi $92,37 \%$.

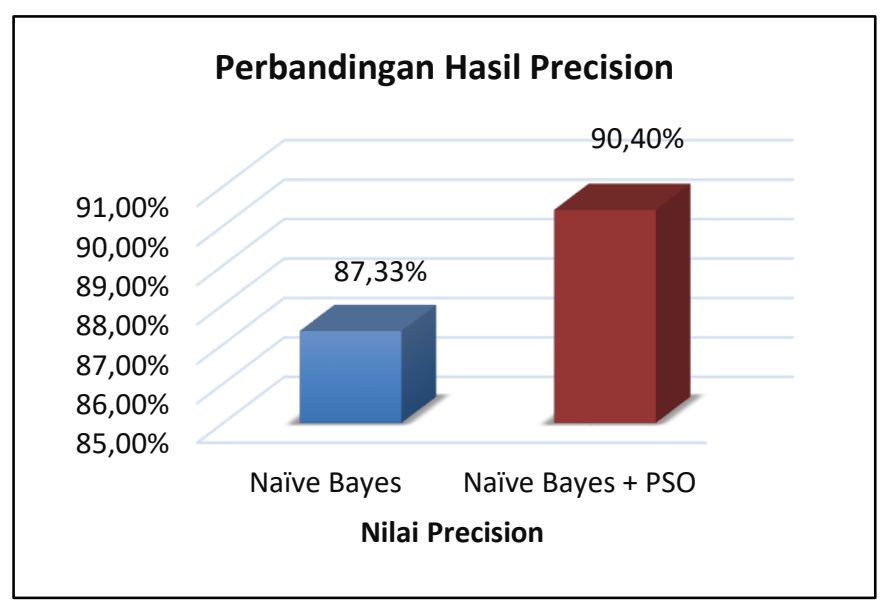

Gambar 22 Grafik perbandingan hasil recall

Dari hasil pengujian yang telah dilakukan antara pengujian pertama dan kedua, pada gambar 22 bahwa nilai precision yang didapatkan meningkat sebanyak 3,07\% dari 87,33\% menjadi $90,40 \%$.

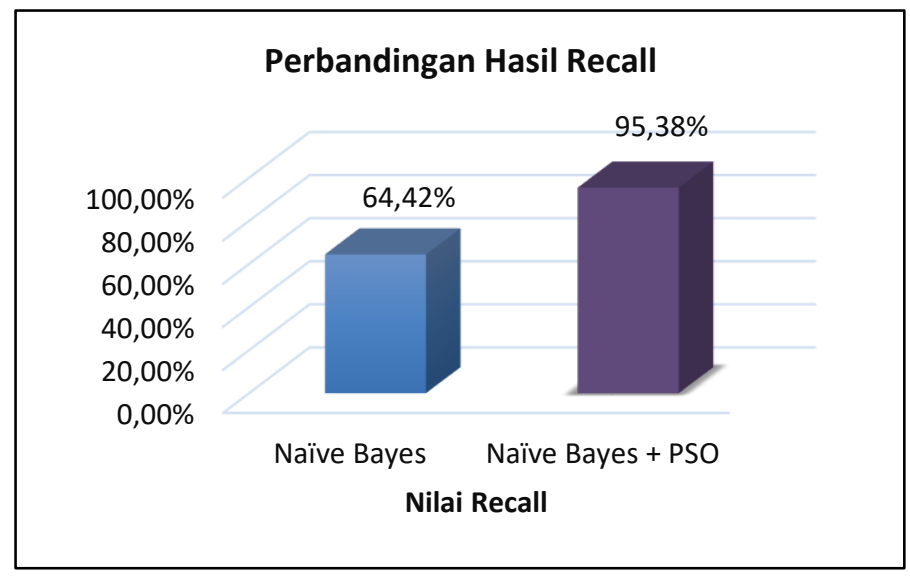

Gambar 23 Grafik perbandingan hasil recall 
Dari hasil pengujian yang telah dilakukan antara pengujian pertama dan kedua, pada gambar 23 bahwa nilai recall yang didapatkan meningkat sebanyak 30,96\% dari 64,42\% menjadi $95,38 \%$.

Table 3 Perbandingan hasil pengujian pertama dan kedua

\begin{tabular}{|c|c|c|c|c|}
\hline \multirow{2}{*}{} & $\begin{array}{c}\text { Pengujian } \\
\text { Pertama }\end{array}$ & $\begin{array}{c}\text { Pengujian } \\
\text { Kedua }\end{array}$ & \multicolumn{2}{|c|}{ Keterangan } \\
\cline { 2 - 5 } & Naïve Bayes & NB+PSO & Peningkatan Nilai & Hasil \\
\hline Accuracy & $77,16 \%$ & $92,37 \%$ & $15,21 \%$ & Meningkat \\
\hline Precision & $87,33 \%$ & $90,40 \%$ & $3,07 \%$ & Meningkat \\
\hline Recall & $64,42 \%$ & $95,38 \%$ & $30,96 \%$ & \\
\hline
\end{tabular}

\section{KESIMPULAN DAN SARAN}

\subsection{Kesimpulan}

Berdasarkan hasil pengujian yang sudah dilakukan dapat ditarik kesimpulan yang ada pada penelitian ini bahwa:

1. Pengujian yang dilakukan menggunakan metode Nä̈ve Bayes dan Particle Swarm Optimization sebagai feature selection dalam menganalisis sentimen masyarakat mengenai kebijakan perpanjangan PPKM darurat pada social media twitter hasil klasifikasi yang didapat dari total 302 data tweets, 161 tweets mengandung sentimen positif dan 141 tweets mengandung sentimen negatif.

2. Dapat Diketahui bahwa 53,31\% pengguna twitter setuju dan $46,69 \%$ pengguna twitter tidak setuju dengan perpanjangan kebijakan PPKM darurat yang di terapkan di beberapa daerah di Kepulauan Jawa dan Kepulauan Bali, yang memiliki status zona merah atau daerah yang memiliki risiko tinggi terhadap paparan kasus COVID-19.

3. Penggunaan feature selection Particle Swarm Optimization pada metode Nä̈ve Bayes dalam menganalisis sentimen masyarakat mengenai kebijakan perpanjangan PPKM darurat pada social media twitter dapat meningkatkan nilai accuracy, precision, dan recall. Nilai accuracy yang didapatkan meningkat sebanyak $15,21 \%$ dari $77,16 \%$ menjadi $92,37 \%$, nilai precision yang didapatkan meningkat sebanyak 3,07\% dari 87,33\% menjadi $90,40 \%$, dan nilai recall yang didapatkan meningkat sebanyak $30,96 \%$ dari $64,42 \%$ menjadi $95,38 \%$.

a. Saran

Adapun saran masukan dari penulis untuk penelitian selanjutnya dapat melakukan analisis sentimen dengan menggunakan metode klasifikasi atau teknik feature selection yang berbeda supaya dapat diketahui perbandingan nilai accuracy, precision, dan recall yang di hasilkan. Penelitian yang dilakukan tidak diimplementasikan pada suatu sistem, oleh karena itu dibutuhkan sebuah sistem analisis sentimen masyarakat berbasis website atau android.

\section{DAFTAR PUSTAKA}

[1] N. P. G. Naraswati, R. Nooraeni, D. C. Rosmilda, D. Desinta, F. Khairi, and R. Damaiyanti, "Analisis Sentimen Publik dari Twitter Tentang Kebijakan Penanganan Covid-19 di Indonesia dengan Naive Bayes Classification," Sist. J. Sist. Inf., vol. 10, no. 1, pp. 228-238, 2021, doi: 10.32520/stmsi.v10i1.1179.

[2] Y. Cahyono, "Analisis Sentiment pada Sosial Media Twitter Menggunakan Naïve Bayes Classifier dengan Feature Selection Particle Swarm Optimization dan Term Frequency," J. Inform. Univ. Pamulang, vol. 2, no. 1, pp. 14-19, 2017, doi: 10.32493/informatika.v2i1.1500.

[3] Humas, "Berlaku Mulai 12 Juli, PPKM Darurat Diberlakukan di 15 Kab/Kota Luar JawaBali,” Jul. 09, 2021. https://setkab.go.id/berlaku-mulai-12-juli-ppkm-daruratdiberlakukan-di-15-kab-kota-luar-jawa-bali/ (accessed Sep. 20, 2021). 
[4] B. G. Sudarsono, M. I. Leo, A. Santoso, and F. Hendrawan, "Analisis Data Mining Data Netflix Menggunakan Aplikasi Rapid Miner," JBASE - J. Bus. Audit Inf. Syst., vol. 4, no. 1, pp. 13-21, 2021, doi: 10.30813/jbase.v4i1.2729.

[5] S. Widaningsih, "Perbandingan Metode Data Mining Untuk Prediksi Nilai Dan Waktu Kelulusan Mahasiswa Prodi Teknik Informatika Dengan Algoritma C4,5, Naïve Bayes, Knn Dan Svm," J. Tekno Insentif, vol. 13, no. 1, pp. 16-25, 2019, doi: 10.36787/jti.v13i1.78.

[6] E. Ermawati, "Algoritma Klasifikasi C4.5 Berbasis Particle Swarm Optimization Untuk Prediksi Penerima Bantuan Pangan Non Tunai," Sist. J. Sist. Inf., vol. 8, no. 3, pp. 513528, 2019, doi: 10.32520/stmsi.v8i3.576.

[7] S. Haryati, A. Sudarsono, and E. Suryana, "IMPLEMENTASI DATA MINING UNTUK MEMPREDIKSI MASA STUDI MAHASISWA MENGGUNAKAN ALGORITMA C4.5 (STUDI KASUS: UNIVERSITAS DEHASEN BENGKULU)," J. Media Infotama, vol. 11, no. 2, pp. 130-138, 2015.

[8] R. yana Yanis, "Sentiment Analysis of Bpjs Kesehatan Services To Smk Eklesia and Bina Insani Jailolo Teachers," JUTEI J. Terap. Teknol. Inf., vol. 2, no. 2, pp. 113-122, 2018, doi: 10.21460/jutei.2018.22.105.

[9] E. Putri and T. Setiadi, "Penerapan Text Mining Pada Sistem Klasifikasi Email Spam Menggunakan Naive Bayes," J. Sarj. Tek. Inform., vol. 2, no. 3, pp. 73-83, 2014, doi: 10.12928/jstie.v2i3.2877.

[10] R. P. Sidiq, B. A. Dermawan, and Y. Umaidah, "Sentimen Analisis Komentar Toxic pada Grup Facebook Game Online Menggunakan Klasifikasi Naïve Bayes," J. Inform. Univ. Pamulang, vol. 5, no. 3, pp. 356-363, 2020, doi: 10.32493/informatika.v5i3.6571.

[11] H. Tuhuteru and A. Iriani, "Analisis Sentimen Perusahaan Listrik Negara Cabang Ambon Menggunakan Metode Support Vector Machine dan Naive Bayes Classifier," J. Inform. J. Pengemb. IT, vol. 3, no. 3, pp. 394-401, 2018, doi: 10.30591/jpit.v3i3.977.

[12] K. J. Prayoga, A. Nugroho, and N. Wiyatno, "Komparasi feature selection particle swarm optimization (pso) dengan genetic algorithm (ga) terhadap algoritma naïve bayes pada analisis sentimen twitter," Pros. Semin. Nas. Teknol. dan Sains, no. September, pp. 299314, 2019.

[13] A. Taufik, "Komparasi Algoritma Text Mining Untuk Klasifikasi Review Hotel," J. Tek. Komput., vol. IV, no. 2, pp. 112-118, 2018, doi: 10.31294/jtk.v4i2.3461.

[14] P. S. M. Suryani, L. Linawati, and K. O. Saputra, "Penggunaan Metode Naïve Bayes Classifier pada Analisis Sentimen Facebook Berbahasa Indonesia," Maj. Ilm. Teknol. Elektro, vol. 18, no. 1, pp. 145-148, 2019, doi: 10.24843/mite.2019.v18i01.p22.

[15] Y. Cahyono and S. Saprudin, "Analisis Sentiment Tweets Berbahasa Sunda Menggunakan Naive Bayes Classifier dengan Seleksi Feature Chi Squared Statistic," J. Inform. Univ. Pamulang, vol. 4, no. 3, pp. 87-94, 2019, doi: 10.32493/informatika.v4i3.3186. 